\title{
YAHUDILERIN GÖÇ TECRÜBESINDE KUDÜS'ÜN KONUMU
}

Dr. Öğr. Üyesi Rabia MERT

Sinop Üniversitesi / Ilahiyat Fakültesi / Din Bilimleri

rabiamert@sinop.edu.tr

https://orcid.org/0000-0002-9214-9202

doi: 10.31834/ortadoguvegoc. 928781

Makale Türü / Article Types: Araştırma Makalesi / Research Article Geliş Tarihi / Received: 27 Nisan / 27 April 2021

Kabul Tarihi / Accepted: 17 Haziran / 17 June 2021

Yayın Tarihi / Published: Haziran / June 2021

Yayın Sezonu / Pub Season: Haziran / June

Atıf / Cite: Mert, R. (2021). Yahudilerin Göç Tecrubesinde Kudüs'ün Konumu. Ortadoğu ve Göç, 11(1). ss. 13-41

Intihal / Plagiarism: Bu makale, en az iki hakem tarafından incelendi ve intihal içermediği teyit edildi. / This article has been reviewed by at least two referees and checked via a plagiarism detector.

Copyright $\odot$ Published by Kilis 7 Aralık Üniversitesi, Lisansüstü Eğitim Enstitüsü, Kilis, 79000 Turkey. All rights reserved 


\section{Öz}

Bu makalede Yahudilerin yaşadığı göçlerle Kudüs'ün bağlantısı ele alınmaktadır. Bu amaçla Yahudi geleneğinde Kudüs'e göçün yeri ile tarihte yaşananlar bir arada değerlendirilerek konu incelenmiştir. İsrailoğulları'nın, ataları kabul ettiği ibrahim'in Tanrı'dan aldığı emirle başlayan yolculukları nebi Musa öncülüğünde Mısır'dan çıkışta Tanrı'nın kutsal topraklarda uyulacak kuralları belirlemesiyle devam etmiştir. Kral Davud'un Kudüs'ü fethine kadar gizli kalan şehir, Süleyman'ın mabedi inşasıyla tamamlanmış ve kutsal topraklar ile İsrailoğulları bir araya gelmiştir. Böylece bir kavmin oluşum süreci Kudüs'e yaşanan göçlerle görünür olmuştur. Lakin bu dönem pek uzun sürmemiş, Yahudiler bölgeden sürgün edilmişlerdir. Bundan sonra Yahudiler bir gün Tanrı ile bozulan ilişkilerinin düzeleceği ve buraya tekrar döneceklerinin umudu ile yaşamışlardır. Bununla beraber Yahudilerin buradan sürgün edilmelerinden sonra tarih boyunca kutsal toprak dedikleri Kudüs'e çeşitli göçleri olmuştur. Bunlar Yahudi Krallığı'nın tekrar kurulması gibi birtakım siyasi anlamlar içerse dahi her dönem dini boyutta yani Mesih dönemi ile birlikte anlaşılmış ve toplu bir göç gerçekleşmemiştir. 19. yüzyılda yaşanan göçlerin ise bu bakımdan diğerlerinden farklı olduğu belirtilmiş ve İsrail'in kuruluşunda aliyanın etkisinden söz edilmiştir.

Anahtar Kelimeler: Yahudilik, Kudüs, Göç, Aliya, Mesih.

\section{THE PLACE OF JERUSALEM IN THE MIGRATION EXPERIENCE OF THE JEWS}

\section{Abstract}

This article discusses the connection between Jerusalem and the immigration of Jews. Fort this very reason, the importance of migration to Jerusalem in Jewish tradition and the historical facts were evaluated together. The journeys of the Israelites, which is started with the order of God by Abraham, whose accepted as ancestor, continued under the leadership of Prophet Moses. The 
city, which remained hidden until King David conquered Jerusalem. It was completed with the construction of Solomon's temple and the holy lands and the Israelites came together. Thus, the formation process of a tribe became visible with the migrations to Jerusalem. However, this period did not last long and the Jews were exiled from the region. After that, the Jews lived with the hope that one day their broken relationship with God would be restored and that they would return there again. However, after the exile of the Jews from, the holy land, Jerusalem, there have been various minor migration movements to there. Even though these have some political meanings such as the re-establishment of the Jewish kingdom, each period has been understood in a religious dimension, that is, with the Messianic era, and there was no mass migration. It was stated that the migrations experienced in the 19th century were different from the others and the influence of aliyah was mentioned in the establishment of Israel.

Keywords: Judaism, Jerusalem, Immigration, Aliyah, Messiah.

\section{Giriş}

Genel olarak İsrailoğulları'nın tarihine bakıldığında göçlerin önemli bir yer tuttuğu söylenebilir. Atalar döneminden itibaren hareket halinde olan İsrailoğulları'nın göç ve sürgünleri günümüze kadar çeşitli şekillerde devam etmiştir. İsrail de Yahudilerin Filistin bölgesine olan tarihi bağlarını öne süren siyonist faaliyetler sonucunda dünyanın değişik yerlerindeki Yahudilerin göçü ile kurulmuş, sonrasında da sürgünleri toplama gayesinde olmuş, bu amaçla kapılarını bütün Yahudilerin göçüne açık tutmuştur. Bu noktada göç, İsrail'in varoluş sebebidir, demek yanlış olmayacaktır, hatta mevcut haliyle İsrail, bir göçmen ülkesi konumundadır. Bu anlayışta Yahudilerin Filistin bölgesinde tarihi bağlarının bulunması onlara sınırsız göç hakkı tanır mı sorusu da bir kenarda durmaktadır. 
Bununla beraber modern dönemdeki göçler, Yahudiliğin dini köklerine dayanılarak gerçekleştirilmiştir, dini gerekçelerin merkezinde ise Kudüs bulunmaktadır. Kudüs'ün Yahudiler için neden önemli olduğu sorusu krallık döneminin en önemli sembolü olan Süleyman Mabedi'nin (בית המקדש/Beyt haMikdaş/Kutsal ev) bir zamanlar orada bulunmasıyla açıklanır. Süleyman Mabedi'nin önemi ise Tanrı'nın kutsallığının tezahür ettiği yer anlayışından kaynaklanmaktadır. Yani İsrailoğulları'nın krallık dönemlerindeki toprağın merkezine Kudüs, Kudüs'ün merkezine ise Süleyman Mabedi'nin bulunduğu Sion Tepesi yerleştirilerek krallık ile kutsallık anlayışları birleștirilmektedir. Bu noktada krallık dönemlerine ait umutlarını geleceğe atfederek devam ettirdiklerini de belirtmek gerekiyor. Günlük ve bayramlardaki dualarda bunun yansıması görülmektedir.

"Tanrımız bizi sevinçle toprağımıza getiresin. Tanrımız halkın İsrailoğulları'nın dualarına kulak ver ve mabedinde hizmetini yenile. Gözlerimiz senin merhametle Sion'a dönüşünü görsün. Sürgünde olanlarımızı mabedin avlusunda bir araya getir ve böylece kurallarına uyalım" (Sidur Kol Yaakov, 2006, s. 620-628).

Aynı zamanda şehir, Yahudi geleneğinde kurban, hac gibi ibadetlerin yapıldığı ve dualarda yönelinen kıble olması gibi özelliklere de sahiptir. Böylece Kudüs'ü sadece İsrailoğulları'nın dini hayatının sembolü olarak görmek doğru olmaz, o aynı zamanda Yahudilik'in karakterini ve gelişimini de belirlemektedir. Başka bir ifadeyle Tanrı, Tora ve İsrail halkının uyumu Kudüs ile birlikte anlaşılmaktadır (Cohon, 1925, s. 171-172).

Bahsedilen hususlarla birlikte Yahudiler kendilerini atalarına ארץ (Tanrı'nın ebedi mülk olarak vaat ettiğine inandıkları topraklar ישראל /Eretz Israel/arz-ı mevud) ile tanımlamaktadırlar: 
“Abram doksan dokuz yaşında iken Rab Abram'a göründü, onunla söyleşip dedi: Ben ise işte ahdim seninledir. Ve sana ve senden sonra zürriyetine Tanrı olmak için seninle ve senden sonra zürriyetinle benim aramda ahdimi nesillerince ebedi ahit olarak sabit kılacağım. Ve senin gurbet diyarını sana ve senden sonra zürriyetine ebedi mülk olarak vereceğim" (Tekvin, 17, s. 1-8).

Bu bölge, genel bir çerçeve ile belirtilecek olursa Romalılar tarafından Palestine/Filistin olarak adlandırılan kısmı yani modern dönemdeki İsrail, Batı Şeria ve Doğu Şeria'yı kapsamakta olup merkezinde ise Süleyman Mabedi'nin bulunduğu Kudüs yer almaktadır. Bu bağlamda bütün bir İsrail toprağı Kudüs ve civarı olarak anlaşılmaktadır. Ayrıca Yahudi geleneğine göre vadedilen toprakların merkezi Kudüs'ün kutsallığına saygı duymayan İsrailoğulları yok olmaktadır (I. Krallar, 12, s. 32-33; I. Krallar, 13, s. 134).

Öte taraftan İsrailoğulları sözü edilen topraklarda bir dönem varlık gösterseler de bu kısa sürmüş; uzun asırlar boyunca sürgünlerde yaşamak durumunda kalmışlardır. Burada unutulmaması gereken bir husus da Tanrı'nın ebedi olarak vaat ettiği topraklardaki mevcudiyetlerini ahitlerine sadık kalmalarına bağlı kılmasıdır, aksi takdirde sürgün edilecekleri kendilerine bildirilmiştir:

"Yollarınızı ve işlerinizi ıslah ederseniz sizi bu yerde oturturum. İşlerinizi düzeltirseniz, garibi, öksüzü ve dul kadını mağdur etmezseniz, suçsuz cana kıymazsanız ve başka ilahlara tapmazsanız sizi atalarınıza ebede kadar vermiş olduğum bu diyarda oturturum" (Yeremya, 7, s. 1-7 ).

Bunun nedeni ise Tanrı tarafından seçilen bu toprakların, içinde sadece iyilerin yaşayabileceği ve kötülerin barınamayacağına dair özel bir anlam taşımasıdır. "Memlekette doğru adamlar oturacaklar ve kâmiller orada kalacaklar. Fakat kötü adamlar memleketten 
atılacaklar ve hainler oradan söküleceklerdir" (Süleymanın Meselleri, 2, s. 21-22). İsrailoğulları da bu nedenle sürgün edildiklerini söylemekle birlikte bir gün tekrar İsrail diyarına döneceklerine de inanırlar, zira Tanrı'nın sözünden dönmeyeceğini sadece bunu ertelediğini kabul ederler.

"Mademki sizi virane ettiler, her yandan sizi yuttular ve dile düştünüz, kavmin dedikodusu oldunuz.... Eski halinizde olduğunuz gibi sizde adamlar oturtacağım ve sizi başlangıçta olduğunuzdan daha iyi yapacağım ve bileceksiniz ki ben Rabbim" (Hezekiel, 36, s. 1-15).

Buraya kadar anlatılanlardan sonra şu soruyu sormak gerekmektedir. Bir Yahudi sadece İsrail toprağı denilen Filistin bölgesinde mi yaşamalıdır? Bir Yahudi'nin kutsal topraklarda yaşamasının gerekliliğiyle ilgili bir soru, hukuki bir bağlamda yani Tevrat'ta veya Talmud'da bununla ilgili bir emrin olup olmamasıyla da ilgilidir, bununla ilgili bilgiye aşağıda yer verilecektir. Fakat burada göç tecrübesinin anlaşılması amacıyla Yahudilerin tarih boyunca yaşadıklarına bakmak uygun olacaktır, zira bölgeye niçin göçtükleri ve neden ayrıldıklarının bilinmesi önemlidir. İsrailoğulları'nın Kudüs'e yönelik olduğu kabul edilen üç büyük göçü mevcuttur. Bunlar; ataları İbrahim'in Tanrı'dan aldığı emirle kutsal topraklara gelmesi, Kudüs'e giden yolun başlangıcı olup Tanrı'nın izniyle gerçekleștirilen nebi Musa liderliğinde Mısır'dan çıkış ve Ezra öncülüğünde Babil diyarından Pers Kralı'nın izniyle yapılan göçlerdir. Buna karşın çeşitli nedenlerle gerçekleșen sürgünler neticesinde buradan uzaklaşmak durumunda kalmışlardır. Bunun sonucunda Kudüs'e doğru göç ve Kudüs'ten göç ikileminde oluşturulan bir Yahudi tarihi ile karşılaşılmaktadır. Benzer şekilde göç ve sürgün diyalektiğinde oluşturulan Yahudi geleneğinden de söz etmek mümkündür.

Özetle göç ve sürgünler ile Yahudi tarihi özdeşleşmiştir denilebilir. Yahudi geleneğine göre Filistin bölgesinin İsrailoğulları'na Tanrı tarafından ebedi mülk olarak vaat edildiği kabul edilmesine rağmen 
burada MÖ 993'te Davud döneminde krallığın başlamasından MÖ 586'daki Babil sürgününe kadar geçen dönemde varlık gösterebilmişler sonrasında yaşananlar neticesinde devamlı hareket halinde bir toplum olmuşlardır. Bu nedenle göç, Yahudiler için diğer tarihi olaylardan çok daha fazla anlam içermektedir.

\section{Yahudilikte Göçün Anlamı}

Yahudilikteki göçün anlaşılması için öncelikle aliya kavramının açıklanmasına ihtiyaç vardır. Göç kelimesine karşılık olarak kullanılan aliya (עליה) kavramı yükselmek, cennetin odaları ve yıldızlar gibi anlamlara gelmektedir (Feyerabend, ty, s. 249). Aliya, Yahudilerin yerleşmek amacıyla merkezinde Kudüs bulunan İsrail toprağı denilen bölgeye gelmesini ifade etmek için kullanılmaktadır. Tevrat'ta Pers Kralı'nın Kudüs'te mabedi inşa etmelerine izin vererek Yahudileri göndermesinin anlatıldığı bölümde kullanılan çıksın kelimesinin (II Tarihler, 36, s. 23) aliya ile aynı kökten geldiği iddia edilmiştir. Böylece aliya Kudüs ile birlikte düşünülmekte ve İsrail diyarına/kutsal topraklara girmek de yükselmek olarak anlaşılmaktadır. Öte yandan aliya, siyonizmin ideallerini gerçekleștirmesindeki temel ilkelerinden biri olmasıyla göçten daha fazla anlam ifade etmektedir. Şöyle ki Yahudilerin atalarının yurdunu yeniden inşa etmesi, buna bireysel olarak katılması ve kişinin yeniden oluşturulan ulusun ferdi olarak kendini gerçekleştirmesi anlamlarına da gelmektedir (Louvish ve Skolnik, 2007, s. 660).

Tarih boyunca Yahudi geleneğindeki konumuna bakıldığında göç, dini anlamda kullanıldığı şekilde aliya, kutsal topraklara geri dönüş umudunu işaret etmektedir ki bu açıdan diyasporadaki Yahudi toplumunu ayakta tutan bir öge görünümündedir. Bu noktada aliyanın dini anlamının nasıl oluştuğu önem arz eder. Halaha'da İsrail toprağına yerleşmek ve orada tarım yapılması konusundaki ifadelere bakıldığında kutsal topraklara yerleșmek dini bir yükümlülük gibi görünmektedir. Bu noktada 613 mitzvadan birinin Mısır'da kalıcı yaşamamak olduğuna inanılır. "Rabbin sana verdiği diyara geldiğin 
onu mülk edindiğin vakit... Kavmi Mısıra geri göndermeyecek. Çünkü Rab size bir daha bu yoldan dönmeyeceksiniz, demiștir" (Tesniye, 17, S. 14-16).

Şu halde aliyanın dini bir emir olup olmadığı sorulduğunda Tora veya Talmud'da kesin bir ifade bulunamayarak genellikle Ramban'ın (Nahmanides ö. 1270) görüşlerine yer verilir. Ona göre İsrail topraklarına yerleşmek, tüm nesillerin yerine getirmek zorunda olduğu olumlu bir mitzvadır, yani zorunluluktur. Ayrıca Eretz İsrail'de yaşamak mitzvasının diğer bütün mitzvalardan üstün olduğunu belirtmiştir. (Ramban, Mitzvah, 4, s. 1). Böylece ikincil kaynaklara dayanılarak kutsal topraklara yerleşmenin bir zorunluluk olduğuna hükmedilir. Öte yandan Yahudi din adamlarının aliyayı Talmud'a dolaylı olarak dayandırmak suretiyle kutsal topraklara yerleșmenin öneminden bahsettikleri de belirtilmelidir. Dindar Yahudiler aliyayı kabul ederken bunu Tora'da bahsedilen Tanrı'nın atalara toprakla ilgili yapmış olduğu vaadin gerçekleşmesi olarak anlamaktadırlar.

Bahsedilen hususun anlaşılması için öncelikle Yahudilikte Kudüs'ün öneminden söz edilmelidir. Bu amaçla Tora'ya bakıldığında Kudüs adının bir yerde ỉbrahim'in/Abram Salem/Kudüs kralı Melkizedek ile görüşmesi kısmında geçtiği görülür. Melkizedek ibrahim'i ve ordusunu hoşnutlukla karşılamış kendilerine değerli mallar vermiştir (Tekvin, 14, s. 18-20). Bu anlatıyla ilgili Midraş'taki açıklamalarda Kudüs'ün kutsallığa sahip bir yer olduğu anlamı çıkarılmaktadır; zira Kudüs'e zedek yani doğruluk dendiği ve doğruluğun ona yerleştirildiği ifade edilir. (Midrash Rabbah, Genesis, , xlıI, 6). Diğer taraftan Talmud'da Kudüs'ün bir defa kutsal olarak belirlendiği ve bunun sonsuza kadar devam edeceği söylenilerek şehrin kutsalla bağlantısı pekiştirilmektedir (Berakhot, IV, 54a; Yoma, I, 12a; Kiduşin, IV, 49b).

Şehrin öneminden bahsedildikten sonra Kudüs'e göç konusuna bakmak gerekmektedir. Yahudi literatüründe Kudüs'e göçün, orada 
yaşayanlara verilecek birtakım lütuflardan söz edilerek teşvik edildiği görülür:

“Kudüs'te yaşamayı seçen insanlar kutsanmışlardır. İsrail toprağında yaşamak istemeyen putlara tapan gibi görülür. Bir adam israil'e göçmek ister de karısı istemezse ondan boşanabilir. Bu durum kadın için de geçerlidir. Eğer kadın Israil'e göçmek ister de kocası kabul etmezse boşanabilir. Israil toprağında yaşamak Tora'nın bütün emirlerini yapmak anlamına gelmektedir (Kethuboth, XIII, 110b, B.T.) israil toprağından Babil'e gitmek yasaktır. İsrail'de yaşayan günahsız sayılır. Orada oturanların günahları affedilir. İsrail toprağına gömülen sunağın altına gömülmüş sayılır. İsrail toprağı dışındaki ölüler diriltilmeyecektir (Kethuboth, XIII, 111a, B.T.). Kişi, halkının çoğu putperest olsa bile her zaman İsrail toprağında yaşamalıdır. Hiç kimse çoğunluğu Yahudiler olsa bile İsrail dışında yaşamamalıdır. Çünkü İsrail'de yaşayan kimsenin bir tanrıya sahip olduğu düşünülür ve İsrail dışında yaşayan kimse de Tanrısı olmayan biri olarak düşünülür (Kethuboth, XIII, 110b, B.T.). Herkes İsrail toprağına göçmeye zorlanabilir; ancak hiç kimse oradan çıkmaya zorlanamaz" (Mishnah, Kethuboth, 13, s. 11).

Yukarıda belirtilen hususlara karşın din adamları Kudüs civarına toplu olarak göçü uygun görmez. Şöyle ki din adamlarına göre kutsal metinlerde bahsedilen İsrail toprağına göç, mabed varken geçerlidir. Mabedin olmadığı dönemde Babil’den İsrail toprağına göçmek pozitif bir emri ihlal etmek olarak görülür; çünkü kutsal metinlerde "Rab, onları hatırlayacağım zamana kadar Babil'de kalacaklar, dedi" yazılmıştır (Kethuboth, XIII, 110b, B.T.; Yeremya, 27, s. 12, s. 21-22). Bu ifade İsrailoğulları'nın toplu olarak göçmelerinin yasaklandığını bildirmektedir, ayrıca Yahudilerin dünya uluslarına karşı isyan etmelerini de men etmektedir. (Kethuboth, XIII, 111a, B.T.). Talmud'da geri dönüşü beklerken Yahudilerin yapması gerekenler ise şöyle ifade edilir: "Kefaret için belirlenen tarihler geçti. Şimdi 
mesele tövbe etmek ve iyi amellere bağlıdır. Eğer İsrail tövbe ederse kurtarılacaktır. Bana geri dönün size geri döneyim, yazılmıştır" (Sanhedrin, XI, 97b, B.T.).

Öte taraftan Yahudiler tarih boyunca aliyayı Mesih ile ilişkili şekilde anlamıştır. Başka bir ifadeyle Kudüs civarına toplu göç, ancak Mesih geldiğinde Tanrı'nın eliyle gerçekleşecek bir hadisedir (İşaya, 11, s. 112). Bunun çok önceden Tanrı tarafından belirlenmiş bir hüküm olduğu da anlaşılır. Talmud'da yer alan ifadelere göre dünya yaratılmadan önce Mesih'in adı yazılmıştır ve bu sonsuza kadar sürecektir (Pesachim, IV, 54a, B.T.). Burada başka pek çok bilgi yanında Mesih'in Davud soyundan olduğundan da bahsedilir. Buna göre Davud Hanedanı (Yeremya, 23, s. 5) geri gelecek ve krallık tekrar kurulacaktır:

"Davud oğlu Roma issrail topraklarını kuşatmadan gelmeyecek. Sonra Rab İsrail çocuklarına geri dönecek. Mısır dönüşü gibi İsrailoğulları'nın Kudüs'e tekrar girişi de mucizelere layıktır. Mesih ne zaman gelecektir? Bütün peygamberler günahları vurguladı" (Pesachim, IV, 54a-54b, B.T.; Sanhedrin, XI, 98b-99a, B.T.).

Mesih anlayışı içinde, İsrailoğulları'nın sürgün günlerinin bitmesi ve Kudüs'teki krallık günlerine tekrar dönmeyi barındırmaktadır. Buna karşın kutsal metinlerde Mesih'i bekleyenlerin kutsandığı da yazmaktadır (Sanhedrin, XI, 97b. B.T.) ki bu gerçekleşene kadar Yahudilerin yapması gerekenler, Kudüs civarına göçmek değil tövbe ederek Mesih'i beklemek olarak anlaşılmıştır. Ayrıca Mesih'i beklemek Yahudilik'in iman esaslarından biridir (Meral, 2011, s. 265)

Yahudilerin tarih boyunca yaşadıkları göçlerin bir sonucu da yaşadıkları yerde hep garip/yabancı olarak görülmeleri olmuştur. Bu açıdan herhangi bir ülkede yaşayan bir Yahudi'nin kendisini gerçekten o ülkenin vatandaşı hissedip hissetmediği de sorgulanmıştır, nitekim günlük ve yıllık ibadetlerde krallığın gelmesi 
ve sürgünün bitmesi İsrailoğulları'nın tekrar vaat edilen topraklara yerleşmesi teması bulunur. Bu anlayışla yetişen ve İsrail'e göçmemiş bir Yahudi kendini -ABD veya Rusya gibi- herhangi bir ülkenin vatandaşı kabul edebilecek midir veya en azından iki vatandaşlık ülküsüne mi sahiptir, sorusu ortaya çıkmaktadır.

Diğer taraftan İsrailoğulları, kutsal topraklara hâkim olduğunda orada kendinden olmayanlara/yabancı nasıl davranmalıdır, sorusu da sorulabilir. Bu konuda Tora'ya bakıldığında şu ifadelerle karşılaşılır:

“Garibe haksızlık etmeyeceksiniz. Çünkü Mısır'da gariptiniz. Hiçbir dul kadını ve öksüzü incitmeyeceksiniz. Eğer onları incitirseniz ve bana feryat ederlerse, onların feryadını mutlaka işiteceğim ve sızı kılıçla öldüreceğim. Kadınlarınız dul ve çocuklarını öksüz kalacak" (Çıkış, 22, s. 21-24).

Yine Tora'da şöyle bir ifade bulunur: "Diyarınızda bir garip, misafir olursa onu mağdur etmeyeceksiniz. Sizinle birlikte bulunan garip aranızda yerli gibi olacak ve onu kendiniz gibi seveceksiniz. Çünkü Mısır'da gariptiniz" (Levililer, 19, s. 33-34). Bunların dışında Tora'da pek çok yerde yabancılara iyi davranmaları gerektiğinden söz edilir. Hatta diğer emirlerle karşılaştırıldığında bu konunun bir hayli fazla yer tuttuğu görülür. Bu noktada Yahudilerin Filistin diyarında bulunduklarında kendilerinden olmayanlara nasıl davrandıklarının tarihi süreçteki örnekleri de ayrıca incelenebilir.

\section{Erken Dönem Yahudi Tarihinde Göçler/ Aranan Kudüs}

"Hasadın turfandasını alacaksın ve Rabbin ismine mesken olmak üzere seçeceği yere (Kudüs'e) getireceksin, tapınağa geleceksin ve kâhine vereceksin ve şöyle diyeceksin: Babam göçebe bir Arami idi. Sayıca az olarak Mısır'a inip orada misafir oldu. Ve orada çokça millet oldu. Mısırlılar bize kötü davranıp üzerimize ağır yük yüklediler. Atalarımızın Rabbine feryat ettik. Rab sesimizi işitti, sıkıntımızı gördü. Rab bizi harikalarla Mısır'dan çıkardı. Bizi bu yere getirdi. Bu diyarı süt 
ve bal akan diyarı bize verdi. Ve onu Rabbin önüne koyacaksın ve Rabbe secde edeceksin" (Tesniye, 26, s. 1-10).

Yahudi aileleri her yıl Fısıh/Hamursuz bayramının ilk gecesi, seder (düzen) adı verilen özel bir akşam yemeği için toplanır ve bu yemek esnasında Mısır'dan çıkıştan bahsederek birtakım dualar okurlar, bunlardan biri de yukarıda verilen pasajlar olup bunları her yıl Fısıh sederinde okumaktadırlar. Tabi burada mabed asırlar önce yıkılmış olmasına rağmen neden hala mabedin ayakta olduğu dönemlerde hasat ürünlerinin tapınağa getirilmesi ile ilgili bölümlerin her yıl tekrar edildiği sorulabilir. Şöyle ki İbrahim gördüğü bir rüyette Kenan diyarının zürriyetine verileceğini öğrenmiştir (Tekvin, 15, s. 1-12; s. 18). Bu rüyette dikkat çeken bir husus vardır. Tanrı, toprak vaadinde bulunurken aynı zamanda nebi Musa ile Mısır'dan çıkışa vurgu yaparak zürriyetinin kendilerinin olmayan bir memlekette 400 yıl garip/yabancı veya göçmen olacaklarını ve kulluk edeceklerini bildirmiştir (Tekvin, 15, s. 13; s. 15). Dolayısıyla Fısıh Bayramı'nda anılan Mısır'dan çıkışın İbrahim ile kurulan bir bağı olup bu bağ Yahudiler için önem arz etmektedir. Bu durum ỉbrahim'in ulusu için almış olduğu bir söze dayandırılmaktadır. İbrahim, Rab ile kendisinin yakınlığı gibi bir bağın nesli için de kurulmasını istemiştir. Bunun sağlanması amacıyla Tanrı ile bağları zayıfladığında ve Rab'e itaatsizlik ettiklerinde sürgün ve göçlerle tedip edilecekleri bildirmiştir. Bu nedenle Fısıh Bayramı'nda Tanrı ile aralarındaki uzaklaşmalar neticesinde maruz kaldıkları göçler hatırlanmakta ve Rab göçmenlik günlerinin unutulmamasını istemektedir. "Ve o günde (Fısıh Bayramı'nda) oğluna bildirip diyeceksin. Bu Mısır'dan çıktığım vakit Rab'in bana yaptığı iş içindir" (Çıkış, 13, s. 8).

Bununla birlikte Fısıh Bayramı'nda anılan Arami göçmen babadan da söz etmek gerekmektedir. Bu kimsenin ỉbrahim olduğu konusunda genel görüş vardır. Ibrahim evini terk edip Rab'in kendisine gösterdiği yola çıkmıştır (Tekvin, 12, s. 1). Yahudilik'in kurucu atası kabul edilen İbrahim, Tora anlatılarında görüleceği üzere bundan sonraki hayatını büyük oranda göçmen olarak yaşamıştır. illk 
atalarının göçmen olarak yaşadığı gibi Yahudiler de tarihleri boyunca bulundukları yerlerde yabancı olarak yaşamak durumunda kalmışlardır. Ayrıca İsrailoğulları Mııı'dan kendileri çıkmamış Tanrı tarafından çıkarılmışlardır, yani İsrailoğulları kendileri çıkamaz; ancak çıkarılabilirler. Bunu her Yahudi'nin her dönemde keşfetmesi beklenmektedir.

Yahudilerin Kudüs'e göçlerinin anlaşılması için İbrahim'in bölgeye göçüne daha yakından bakmak uygun olacaktır. Zira ibrahim'in bölgeye neden göç ettiğinin bilinmesi sonrasında İsrailoğulları'nın Kudüs'e göçlerinin sebeplerinin anlaşılması bakımından önem arz eder. Bahsedilen göç için öncelikle şu söylenmelidir, bu Tanrı'nın isteği ile gerçekleşmiş bir olaydır (Tekvin, 12, s. 1). Bu konuda Apokrif kaynaklarda farklı bilgiler de bulabilmekteyiz. The Apocalypse of Abraham'da yer alan ifadelere göre İbrahim, putperestliğe karşı olup bunun için babası ve kavmiyle mücadele etmiştir, göçü de putperest kavmi ile mücadelesi sonrasında olmuştur (The Apocalypse of Abraham, I-VIII). Buna göre bulunduğu yerden ayrılmasının sebebi herhangi bir toprağı mülk edinmek olmayıp Tanrı'ya özgürce ibadet edebilmektir. Ayrıca o, Kenan diyarına geldiğinde de bir yerde meskûn olmayıp çeşitli yerlere göçmüştür. Hatta kıtlık nedeniyle buranın dışında bulunan Mısır'a gittiği de Tora'da anlatılmaktadır (Tekvin, 18, s. 1; Tekvin, 12, s. 5-10; Tekvin, 13, s. 1-4).

Bununla beraber İbrahim'in Kenan diyarında bulunduğu sürede çeşitli yerlere Tanrı'ya kurban sunmak için mezbah inşa ettiği görülüyor. Bunlar; Şekem denilen More meșeliğinde, Beyt-el'in doğusunda ve Hebron'daki Mamre meşeliğinde olup birden fazla yerde ibadet alanı kurulduğu görülüyor. Burada dikkat çeken bir husus da İbrahim'in Mısır'da bulunduğu sürede herhangi bir mezbahtan söz edilmemesidir. Sonrasında o, Hebron'daki Makpela mağarasını satın almış, eşi ve kendisi buraya defnedilmiştir (Tekvin, 12, s. 6-10; Tekvin, 13, s. 18; Tekvin, 25, s. 9-10). Kudüs'te Süleyman Mabedi'nin kurulduğu tepe ile bağlantısı ise oğlu İshak'ı kurban etme hadisesi vasıtasıyla kurulmaktadır (Tekvin, 22, s. 2). Midraş'ta 
Ibrahim'in neden Kudüs'e yerleşmediği açıklanarak buna Tanrı tarafından izin verilmediği belirtilmektedir; "Çünkü Abraham Tanrı'nın kendisine söylediği gibi gitti” (Midrash Rabbah, Genesis, Ivı s. 2; Tekvin, 12, s. 4).

İsrailoğulları'nın Kenan diyarından Mısır’a toplu olarak göçü Yakup döneminde gerçekleşmiştir. Bu göçün nedeni genellikle Kenan Diyarı'nda yaşanan kıtlık kabul edilir. Bunun yanında Tora'da Yakup'un Mısır'a göçüne Tanrı'nın izin verdiği de görülmektedir: "Rab İsrail'e rüyasında Mısır'a inmekten korkma dedi. Seni orada büyük bir millet edeceğim, Mısır'a ben seninle beraber ineceğim" (Tekvin, 45, s. 5-7; Tekvin, 47, s. 4; Tekvin, 46, s. 1-4). Mısır'a göç kıtlık nedeniyle ve Tanrı'nın izin vermesiyle gerçekleşmiş ve İsrailoğulları yine Tanrı'nın dilemesiyle Mısır'dan ayrılarak Kenan diyarına doğru yola çıkmışlardır (Çıkış, 3, s. 8). Böylece onlar göçebe olarak Kenan Diyarı'na geldiler, zaten atalar döneminde de konargöçer olarak yaşıyorlardı, yerleşik bir düzenleri yoktu (Tekvin, 46, s. 32-34). Burada şunu da söylemek gerekiyor, Musa öncülüğünde Mısır'dan çıkış, sadece İsrailoğulları'nın kutsal topraklara yolculuğu olarak anlaşılmamakta bunun yanında kavmin efendi olmasının da başlangıcı olarak görülmektedir.

Öte yandan Tora'daki Musa anlatısında da ibrahim örneğinde olduğu gibi İsrailoğulları'nın Mısır'da bulundukları sürede herhangi bir mezbah inşasından söz edilmez. Tek görünen Musa'nın, Mısır'dan kavmi çıkarmak dileğiyle Firavun'a gittiğinde ona üç günlük yol gidip kurban sunmak isteklerini bildirmesidir (Çıkış, 3, s. 18; Çıkış 5, s. 3). Nitekim ilk Fısıh kurbanı, Mısır'dan çıkıştan sonra gerçekleştirilmiştir (Çıkış, 12, s. 1-14). İbrahim'in ve Musa'nın kurban ibadetlerinde sadece Kenan Diyarı'nın adının anılması burasının Tanrı'nın seçtiği yer olmasıyla açıklanmaktadır. Dolayısıyla bu İsrailoğulları'nın Filistin bölgesinde ibadet mekânı edinmekle birlikte; fakat başka yerlerde de yaşayabileceğini göstermektedir. Anlaşıldığı üzere ilk dönemlerde Kudüs civarına göçler Tanrı'nın isteğiyle gerçekleştirilmiştir ve bunlarda öne çıkan husus Tanrı'ya ibadet 
etmektir. Böylece İbrahim ile başlayan arz-ı mevuda göç, Musa öncülüğündeki çıkışta görünür olmuştur; fakat Yahudi tarihindeki bu iki büyük göç de Kudüs ile irtibatlandırılmalarına karşın görünür herhangi bir bağı bulunmamaktadır. Öyle ki Musa'nın vaat edilen toprakları bile görmediği Yeşu'nun da Kudüs'ü fethetmediği bilinmektedir. Hatta bu konuda görünür bir gayretin dahi olmadığı belirtilmelidir (Hasanoğlu, 2015, s. 132).

İsrailoğulları, Filistin bölgesinde göçebe olarak uzun müddet yaşadıktan sonra Kral Davud ve oğlu Süleyman'ın krallıkları döneminde altın çağlarını yaşamışlardır. Aynı zamanda Kral Davud döneminde Kudüs, fethedilip başkent yapıldığında Ahit Sandığı'nın buraya getirilmesiyle şehir Yahudi tarihi için ortaya çıkmış oldu (II. Samuel, 6, s. 17-19; 5, s. 6- 7). Sonrasında oğlu Süleyman döneminde mabedin inşa edilmesiyle ise şehrin önemi artmıştır (I. Krallar, 6, s. 1; 8, s. 1-10). Böylece Kenan Diyarı'nın en kutsal yeri Kudüs kabul edilmiştir. Ayrıca şehir, Yahudi ibadetlerinin merkezi olması yanında İsrailoğulları'nın krallık dönemlerinin de en önemli sembolü olmuştur. Buna karşın İsrailoğulları Tanrı'nın yardımı ile elde ettikleri bu yerde Tanrı'ya verdikleri sözü koruyamamış, Tanrı'nın gazabını üstlerine çekerek toprak üzerindeki haklarını kaybetmiş ve sürgün edilmişlerdir. Bununla birlikte sürgün dönemi peygamberleri olan İ̧̧aya, Yeremya ve Hezekiel anlatımlarında Kudüs motifi dikkat çekmektedir. Şöyle ki bahsedilen metinlerde sürgün, günahlarının cezası olarak sunulmakta ve tekrar dönüş umutlarında Kudüs yer almaktadır (İşaya, 52, s. 7-11). MÖ 586'daki sürgünden dönüşte ise toprağın daha fazla öne çıktığını söylemek mümkündür.

Görüldüğü üzere İbrahim'in Filistin'e göçüyle başlayan yolculuk Musa döneminde devam etmiştir. Kudüs, bu süreçte İsrailoğulları'nın göçebe hayattan yerleşik hayata geçiş noktası olmuştur. Sonuç olarak erken dönemlerde İsrailoğulları'nın Filistin'e göçünün sebeplerine bakıldığında Tanrı'nın isteğini yerine getirmek amacıyla yapıldığı görülür. Bundan sonraki dönemlerde ise 
İsrailoğulları'nın göçleri daha ziyade Filistin bölgesinden başka yerlere sürgün şeklindedir.

\section{Babil Sürgünü ve II. Mabed Tahribi Sonrasında Yahudi Göçleri}

Babil Sürgünü, Yahudilerin tarihine yansıyan göçün sonuçları açısından önem arz etmektedir. Nitekim yabancı bir ülkede iken Kudüs'te oturmayan ve mabedi bulunmayan Yahudiliğin nasıl ayakta kalacağı sorunu ile yüzleşmek durumunda kalmışlardır. Burada yeni bir Kudüs motifi ile karşılaşmaktayız. Şöyle ki mabedin inşa edilmesinden itibaren kurbanların sunulduğu ibadet mekânı olarak öne çıkarken sürgün günlerinde dualarda anılan ve ibadetlerin yöneldiği bir mekâna dönüşmüştür. Babil Sürgünü dönüşü mabed tekrar inşa edilerek ibadetler başlasa dahi kurbanların yerine ikame edilen dualar devam etmiştir (Güç, 2003, s. 248). Babil'de sürgünde iken gerçekleşen Hezekiel'in rüyeti, Yahudilerin Tanrı tarafından affedilerek tekrar eski günlere dönüleceğinin umudunu vermektedir ve bunun merkezinde Kudüs vardır. Hezekiel'e "Kendine bir tuğla al Onu önüne koy üzerine bir şehir çiz Kudüs'ü çiz" denilmiştir. Bu rüyette Hezekiel, ateş saçan bulut içinde gelen bir araba görmüş ve bazı sembollerle gelecekte İsrailoğulları'nın Kudüs'te yaşayacakları kendisine anlatılmıştır (Hezekiel, 1, s. 1; 1, s. 15; 4, s. 1-16; 5, s. 13; 8, s. 3; 8, s. 5). Diğer taraftan sürgün dönüşü kavmin toprakla bağları daha da kuvvetlenmiştir. Çünkü uzak diyarlara dağılmış olan İsrailoğulları'nın ayakta kalabilmesi için tekrar bölgeye bağlanması gerekmiştir, bunun merkezine de Kudüs yerleștirilmiştir.

Bu dönüşten sonra bir defa daha Roma tarafından MS 70'de sürgün edilmişlerdir. Romalılar Kudüs'ü tahrip etmiş Yahudileri de bölgeden çıkarmışlardır, ayrıca onlara şehre giriş yasağı da getirmişlerdir (Mishnah, Ta'anit, 4, s. 6). Bu sürgünden sonra Kudüs'te bir Yahudi varlığının bulunup bulunmadığı konusunda MS 132-135 yılları arasındaki Bar Kohba ayaklanması bir fikir verebilir. Aynı şekilde Bizans tarafından da Yahudilerin Kudüs'e girişi yasaklanmış, şehre girdiği tespit edilenler ölümle cezalandııımıştır (Hayland, 1997, s. 
127). Bu yasaklar halkın çoğunluk oluşturacak şekilde Kudüs civarında yaşamasını engellemiştir. Bunun yanında Yahudi geleneğinde de Mesih gelinceye kadar Kudüs dışında yaşamanın kabul edilmesiyle bölgeden uzaklaşmışlardır. Bir taraftan Mesih'in gelmesi beklenirken diğer taraftan bir kısım Yahudilerin bu bölgeye yerleştiği de bilinmektedir; lakin bu topluca göç şeklinde gerçekleşmemiştir. Bu bağlamda Roma ve Bizans dönemlerinde Kudüs'te bulunan Yahudilerin sayısına bakıldığında net bilgilere ulaşmak zor görünmektedir. Lakin yine de Filistin bölgesindeki en kalabalık şehrin Kudüs olduğu anlaşılmaktadır (Broshi, 1979, s. 1, 5).

Burada bir hususa daha yakından bakmak gerekmektedir. MS 70 tarihinde gerçekleşen II. Mabed tahribinden sonra dünyanın çeşitli yerlerine dağılan Yahudilerin Filistin bölgesine göçleri var mıdır, varsa sebepleri nedir ve nasıl gerçekleşmiştir? Dini merkez olarak Yavne'yi edinmelerine karşın yine de Talmud ve diğer Yahudi literatüründeki bilgilerden Kudüs'te az sayıda dindar Yahudi'nin varlığını devam ettirdiği anlaşılmaktadır. Babil ve Kudüs Talmudları'nın oluşturulduğu dönemde (MS 220-470) Babil akademileri üstün bir konumda olmasına rağmen Kudüs'e çeşitli göçlerle karşılaşılmaktadır. Buradaki göçlerin nedenine bakıldığında daha çok dini amaçla, manevi bağlılık arzusuyla yapıldığı düşünülmektedir. Örneğin Kudüs'teki din bilginlerinden eğitim almak niyetiyle birtakım göçler yaşanmıştır. Bunun dışında Kudüs'te bulunan Sanhedrin'e boşanma gibi bazı halahayla (Yahudi Fıkhı) ilgili konularda sorular sormak için çeşitli yolculuklar yapıldığı bilinmektedir, bunlar önemsiz göç hareketleri olarak görülmelidir; yine de bu amaçla gidenlerden bir kısmının bölgeye yerleşerek geri dönmediği de söylenmelidir. Bunların dışında halkın bazı ekonomik sebeplerle göçleri de olmuştur (Schwartz, 1981, s. 317 - 321). Bu bağlamda Rabbi Aha of Shabha'nın (ö.752) Babil'den ayrılarak Kudüs civarına yerleştiği de bilinmektedir. Neden göç ettiği konusunda net bilgiler olmamakla birlikte Babil'de yaşadığı ekonomik sıkıntılardan bahsedilmektedir (Ginzberg, 1909, s. 75). Ayrıca dünyanın çeşitli 
yerlerinde yaşayan Yahudilerin bir zulümle karşılaştığında Kudüs'e göçtüğünden de bahsedilmektedir (Baba Kama, X, 117a, B.T.)

Hz. Ömer, Kudüs'ü fethettiğinde şehirde Yahudi nüfusundan söz edilmemektedir. Yukarıda birkaç paragrafta ifade edildiği üzere şehirde Yahudi nüfusu sayılabilecek halk kesiminden söz edilememektedir; lakin yasaklar ne kadar katı uygulanmaya çalışsa da burada din adamı olan az sayıda kimsenin bulunduğu ve hac için gelen yaşlı Yahudilerden bir takım kimselerin buraya gömülmek umuduyla şehirde kaldığı da unutulmamalıdır. Müslümanların Kudüs'ü fethinden sonra Yahudilerin şehre yerleșmesine izin verilmesi üzerine Yahudilerden 70 ailenin gelerek Tapınak Tepesi'nin kapılarından birinin yakınlarına yerleştiği bilinmektedir (Gil, 1992, s. 70-72) Buradan anlaşıldığı üzere Yahudilerin Kudüs'e yerleşmelerine müsaade edilmesine rağmen bütün Yahudilerin bölgeye göç teşebbüsü olmamıştır. İslam ülkesi sınırları içinde Teyma ve Vadi'lKurâ gibi diğer yerlerde meskûn olan Yahudiler yaşamlarına devam etmiştir. Bununla birlikte Hayber'den çıkarılan Yahudilerin de Kudüs'e değil Eriha bölgesine gittiği bilinmektedir (Fayda, 1989, s. 184). Görüldüğü gibi İslami dönemde Yahudiler istedikleri yerde yaşama hakkına sahip olmuşlardır, bunun neticesi olarak da Kudüs'te olduğu gibi başka yerlerde yaşayan Yahudiler bulunmuştur. Öte taraftan Kudüs'e çeşitli sebeplerle Yahudi göçü ile de karşılaşılmaktadır; bunlar hac yolculukları gibi dini amaçlar yanında oraya gömülmek arzusunda olan yaşlı veya dindar kimseler tarafından yapılmış olup İslami dönemde şehre toplu olarak bir Yahudi göçü bulunmamaktadır (Arslantaş, 2011, s. 653; s. 659).

Buraya kadar verilen bilgilerden anlaşılacağı üzere yasaya uygun olarak tarih boyunca Yahudiler, Kudüs civarına toplu olarak göçmeyi uygun bulmamışlardır. Bu nedenledir ki göçlerini engelleyen durumlar -Roma dönemindeki giriş yasakları gibi- olmadığında dahi dünyanın çeşitli yerlerinde yaşayan Yahudiler bulunmuştur. Sürgün sonrasındaki dönem boyunca Yahudilerin Kudüs'e göçleri çoğunlukla buraya gömülmek gibi çeşitli dini nedenlere 
dayanmaktadır. Avrupa'da yaşayan Yahudilerin kötü muameleye maruz kalmaları sonucunda 13. ve 19. yüzyıllar arasında birtakım göçler yaşanmıştır. Örneğin 1290'da İngiltere'den, 1391'de Fransa'dan, 1421'de Avusturya'dan ve 1492'de İspanya'dan çıkarılmışlardır. Bunlar bir kısım Yahudiler tarafından kurtuluşun yaklaşması olarak algılanmış ve Kudüs'e göçlere neden olmuştur (The Jewish Virtual Library. Aliyah in Judaism.)

\section{Modern Dönemde Yahudi Göçü/ Siyasi-Mesihi Görüșler Arasında Kudüs}

Yahudi halkı tarih boyunca aliya isteğinde olmuş ve bu amaçla çeşitli hareketleri bulunmuştur. Ancak 19. yüzyılda ortaya çıkan ve Filistin bölgesinde bir Yahudi devleti oluşturmak amacıyla dünya üzerindeki Yahudilerin göçünü teşvik eden siyonizme kadar bölgeye toplu olarak göçleri mevcut değildir. Modern dönemde siyonizm, İsrail toprağı denilen bölgeye toplu göçü başlatmıştır. Peki, İsrail'in oluşum sürecinde dünyanın çeşitli yerlerinde yaşayan Yahudilerin buna bakışı nasıl olmuştur? Genel olarak cevap vermek gerekirse İsrail toprağına göç, siyonistler dışındaki Yahudiler tarafından dini bir zorunluluk olarak görülmeyip bireysel tercihlere bırakılmıştır.

Bununla beraber konunun daha iyi anlaşılması için o dönemdeki Yahudi mezheplerinin görüşlerine bakmak uygun olacaktır. Ortodokslar; bunun Tanrı'nın işi olduğunu söyleyerek, Mesih dönemine işaret etmişlerdir. İsrail'de yaşama zorunluluğu konusunda da Süleyman Mabedi'nin mevcut olduğu dönemlere ait olduğunu söyleyerek bu ilkenin günümüzde geçerli olmadığını belirtiyorlar. Mabed yıkılıp Yahudiler sürgün edildikten sonra bunun uygulanması gereken bir mitzva olmadığına inanıyorlar. Ayrıca İsrail topraklarında uygulanması gereken birçok mitzva ve yasak olduğundan tüm bu yükümlülükleri yerine getirmenin zorluğundan da bahsedilmektedir (Bleich, 1979, s. 59; Zakutinsky, 2016). Yine de bu gruptan kimselerin bir zorunluluk kabul etmemekle birlikte İsrail'e giderek orada yaşamayı tercih ettiğini söylemek gerekiyor. 
Bunların amacı ise kutsal topraklarda ölmek ve oraya gömülmek isteği olup dini nedenlere dayanmaktadır ve bu kimseler genellikle Kudüs'e yerleşmektedir.

Muhafazakâr Yahudiler, göç konusunda arada bir duruşu tercih etmişlerdir. Buna göre İsrail topraklarına toplu göç zorunluluk olarak görülmemiş; lakin ataların toprağı olduğu söylenerek kişilerin seçimine bırakılmıştır (Schechter, 2007, s. 216). Dolayısıyla kutsal topraklara topluca bir göç için çağrıda bulunmamışlardır. Bununla birlikte göçenlerin kalanlardan daha önemli kabul edildiği anlaşılmaktadır.

Reformistler ise önceleri issrail toprağına göç konusundaki görüşlerini Pittsburgh Platformu'nda açıklayarak buna karşı çıkmışlardır: "Kendimizi artık ulus olarak değil, dini bir topluluk olarak görüyoruz. Ne Filistin'e dönüşü ne de kurban ibadeti ve Yahudi devleti ile ilgili yasaların tekrar başlamasını beklemiyoruz" (Pittsburgh Platformu, 1885, Madde 5). Bu doğrultuda Avrupa'da yaşanan antisemitik hareketlerin etkisiyle ilk başlarda Filistin bölgesine değil Amerika'ya göçmüşlerdir. Amerika'da bulunan Yahudiler de ilk zamanlar "Amerika bizim Kudüs'ümüzdür”, diyerek Filistin bölgesi ile bağlarını reddetmişlerdir (Raphael, 1973, s. 201). Daha sonraları ise antisemitik hareketlerin etkisiyle büyük oranda ABD'de yaşayan Reformist Yahudiler de bölgeye göçü dini anlamda olmasa da kabul etmek durumunda kalmıştır. Bu gruptaki Yahudilerin genellikle daha az dini anlam taşıyan Tel Aviv gibi yerlere yerleștikleri görülmektedir.

Siyonistler, bu konuda en dikkat çeken grup olmuştur. Hatta aliya fikri siyonizmin temel taşlarından biri olmuştur. Bu amaçla Filistin bölgesine göçü teşvik etmiş, bunun için gayret sarf etmişlerdir. Aynı zamanda Yahudileri göçe zorlamaya karşı olduklarını da belirtmişlerdir; fakat bunun göç konusundaki gelenekteki görüş nedeniyle diğer gruplarla çatışmamak adına olduğu unutulmamalıdır (Glass, 2018, s. 37; s. 47; s. 57; s. 60). Siyonizm, Filistin bölgesinde Yahudi devleti oluşturmak için teşvik ettiği göçler için aliyayı dini 
argüman olarak kullanmıştır. İsrail'in Kudüs'ü başkent edinme yönündeki ısrarı da şehrin aliya fikrinin merkezinde yer alması nedeniyledir. Burada dikkat çeken husus ise İsrail'e göçler dini köklerine dayanılarak gerçekleștirilmektedir; ancak bölgeye gelindiğinde yine siyonizmin etkisiyle dini köklerle bağlar koparılmaya çalışılmaktadır (Halamish, 2018, s. 105; s. 110).

Öte taraftan siyonistlerin İsrail toprağı denilen bölgede bir Yahudi devleti oluşturma çabası da zaten geleneğin bir hayli dışındadır. Bu nedenledir ki öncelikle Yahudileri buraya göçmeye ikna etmeleri gerekmiştir, sonrasında da burada Yahudilerin nasıl bir varlık göstereceği tartışılmıştır. Örnek olarak Herzl'in etkisiyle siyonizm taraftarları arasına katılan Franz Oppenheimer'in Merchavia adlı eserine bakılabilir. Eserinde o, Filistin'e yoğun bir Yahudi göçünün mümkün olup olmadığını sormakta, bunun gerçekleşmesi için bölgenin tarıma elverişli hale getirilmesinden bahsetmektedir. Eğer gayret gösterilirse burada modern tarım yapılabileceğini savunmaktadır. Bunun için siyonist organizasyonun en kısa sürede Filistin'de gelişmiş tarımı kurmasını önermektedir. Burada özellikle fakir Yahudilerin göçü önem kazanmaktadır. Buna karşın yoğun şehirli nüfusun göçüyle yüzleşilmiştir. Neticede karşı karşıya kalınan bu sorun Yemen'den gelen fakir Yahudilerin yerleşimiyle çözülmüş oldu. Böylece Merchavia-Kudüs hattında küçük tarım alanları oluşturuldu (Oppenheimer, 1914, s. 1-4; s. 22-24). Burada şu hususun da belirtilmesi gerekir ki buraya yaşanan yoğun Yahudi göçünün başııa etkisi Arap çiftçiler üzerinde görülmüştür, çiftçiler yaşanan süreç sonunda büyük oranda topraklarından çıkarılmışlardır.

Filistin bölgesine aliya yapmak konusuna Yahudilerin bakışlarının belirtilmesinden sonra tarihi sürecin nasıl geliștiğine bakmak gerekmektedir. Bölgede üç dinden inananların yaşadığı bir yönetim anlayışını benimseyen Osmanlı egemenliğinin yerine I. Dünya Savaşı'nın sona ermesiyle İngiliz manda yönetimi başlamıştır. İngilizler, Balfour Deklarasyonu'na uygun şekilde siyonistlerin yürüttüğü aliya faaliyetlerine izin vermişlerdir; lakin bu bildiride 
Filistin bölgesinde Yahudiler için bir yuvadan söz ederken onları dini bir grup olarak değil ulus olarak gördükleri de belirtilmelidir. İngilizler tarafından 1922'de yapılan nüfus sayımına göre Kudüs'te 28.600 kişinin yaşadığı tespit edilmiştir. Bunların \% 80’i Müslüman, \% 10'u Hıristiyan ve \% 7'si ise Yahudilerden oluşmaktadır. Otuz yıl süren manda dönemi sonunda ise Kudüs'ün nüfusu 60.00'e yükselmişti ki bunun nedeni gerçekleşen yoğun Yahudi göçleridir. Bu göçler neticesinde buradaki Yahudilerin sayısı neredeyse Müslümanlara eşit konuma ulaşmıştır (Hagopian ve Zahlan, 1974, s. 36; s. 40).

Avrupalı devletlerin Yahudilerin Filistin'e göçünü teşvik etmeleri Nazi Yönetimi sonrasında devam etti. Zira Avrupa devletleri bundan sonra Yahudilerin nerede yaşayacağı sorunu ile karşılaştı. Şöyle ki Nazi Yönetimi sona erdiğinde hayatta kalan Yahudiler işlerine ve eski evlerine dönmek istediklerinde bu kabul edilmemiştir. Evleri ve işlerini başkaları tarafından ele geçirilmiş bulunuyordu. Ayrıca Yahudiler ölüm tehlikesinden kurtulmuş görünseler de toplumda istenmeyen insanlar olmaya devam etmişlerdir. Dolayısıyla yaşanan olumsuz hadiselerden sonra toplumda istenmeyen insanlar olarak ortada kalan Yahudilerin Avrupa'dan gönderilmesi için çareler aramaya başlamışlardır. Bu amaçla Yahudilerin ABD'ye göçü teşvik edilmiştir; fakat ABD'ye daha fazla göçmen kabul edilemediğinde durum Yahudilere karşı sorumluluk hisseden Avrupa devletleri ve Yahudiler için iyice ciddileşmiş oldu. Bu nedenle savaştan sonra Yahudilerin göçü desteklenmiştir. Avrupa kolonileri (MadagaskarAlaska gibi), tropik Afrika ve Kuzey kutbu bölgeleri de gerçekçi olmaktan uzak bulundu. Arjantin'deki Yahudi yerleşimi teşviklere rağmen başarısız oldu. Burada tek gerçekçi umut Filistin bulundu (Jewish Case, ty, s. 3-6). Filistin, Yahudilerin tarihi ve dini bağları nedeniyle sadece göçmen olacakları değil aynı zamanda vatan olarak bağlanabilecekleri bir yer olarak görülmüștür. Böylece Yahudi sorununa da kalıı bir çözüm sunulmuş oluyor ve Avrupalıların iyiliği için Yahudilerin evsizliğine son verilmeye çalışılıyordu. 
Görüldüğü gibi bir taraftan siyonistler aliyayı desteklerken diğer taraftan başka şartlar tarafından da uygun ortam hazırlanmıştır. İsrail'in kurulmasının öncesindeki dönem Filistin bölgesinde Avrupalı devletlerin konsolosluklarının görünmeye başladığı sürece denk gelmiştir. Ayrıca Hıristiyan milenyarist görüşlerde Yahudilerin kutsal topraklara dönmesi Mesih'in gelmesinin ön şartı olarak anlaşılır, bu nedenle daha fazla Yahudi göçü buna da uygun görülerek desteklenmiştir. Yaşanan yoğun göçler ile bölgede bir Yahudi varlığı oluşmuştur ki bu da siyonistlerin istediği şeydir. Neticede siyonist faaliyetler ile emperyalist devletlerin çıkarlarının örtüşmesiyle de bölgede bir siyonist Yahudi devlet ortaya çıkmış oldu (Scholch, 1992, s. 40-46).

İsrail, 14 Mayıs 1948 tarihinde bağımsızlığını ilan ettikten sonra 1950'de - Law of Return/Geri Dönüş Yasasını çıkarttı (İsrail Dış İşleri Bakanlığı, 1950). Buna göre dünyanın herhangi bir yerinde yaşayan bir Yahudi, İsrail'e gelmesi halinde vatandaşlık hakkı kazanmaktadır. Böylece kutsal topraklara dönüş umudu olan aliya, geri dönüş yasası ile resmi bir kimliğe bürünmüş oldu. İsrail vatandaşlı̆̆ı, birtakım maddi teşvikler de içermektedir. Bu da fakir Yahudilere cazip gelmektedir. Örneğin Arap ülkelerinde (Yemen, Irak gibi) yaşayan Yahudilerin İsrail'e göçü iyi şartlarda yaşama isteğine dayalı olup daha çok ekonomik nedenlerle gerçekleştirilmektedir (Hassan, 2017, s. 887$)$.

Buraya kadar aktarılan bilgiler doğrultusunda İsrail'in kuruluşunda en önemli unsur olarak görülen aliyalar şu şekilde gerçekleşmiştir: ilk olarak 1800'lerde bölgeye Yahudi göçleri başlamıştır, ancak bunlar önceleri şahsi ve küçük gruplardan oluşmakta olup önemli sayıda olmamıştır. Bu bağlamdaki aliyalardan biri 1882-1905 arasında Rusya'dan gelen Yahudiler olup, küçük gruplardan oluşmaktadır. íkinci aliya 1904-1914 arasında Rusya'dan yapılmıştır ve işçi hareketin etkisindeki insanlardan oluşmaktadır. Bu dönemde ibranice canlandırılmıştır ve bu İsrail'in kuruluşunun ilk adımı olmuştur. Üçüncü aliya 1919-1923 tarihleri arasında I. Dünya savaşının hemen 
sonrasında İngiliz mandasında iken gerçekleşmiştir. Dördüncü aliya 1924-1928 arasında yaşanmıştır, genelde orta sınıf insanların göçüdür, antisemitizmin etkisi olmuştur. Beşinci aliya 1929-1939 tarihlerinde Nazi Almanya'sından kaçan insanlardan oluşmaktadır. Bunlar genelde eğitimli insanlardır. 1990'larda Sovyetler Birliği yıkıldığında ise bir milyondan fazla Yahudi İsrail'e gelmiştir (Louvish ve Skolnik, 2007, s. 661-662). Bu sayılan beş aliya dışında göçler de olmuştur. 1949-1950 tarihlerinde Yemen aliyaları ile 1985 ve 1991 tarihlerinde Etiyopya aliyaları yapıldı. Bunlar kişilerin kendi göçleri olmayıp operasyonlar neticesinde uçaklarla gerçekleştirilmiştir. Ayrıca 1993'ten sonra yapılan göçler, antisemitizm tehdidinden ziyade ekonomik nedenlere dayanmaktadır (Siegel, 2018, s. 417). Böylece Avrupa'dan, Kuzey Afrika'dan ve Orta Doğu'dan Yahudiler gelmiş oldu (The Jewish Virtual Library. Israel Studies An Anthology). Bununla birlikte bahsedilen aliyaların dini anlamı yanında seküler anlamının da bulunduğu ifade edilmelidir.

Son on yılda ise İsrail'e diğer yerlerden yapılan aliyalar azalmış olup, ayrıca İsrail'den ayrılarak ABD gibi çeşitli yerlere göçenlere de rastlanmaktadır. Bu duruma bölgenin devamlı savaş tehdidi görünümünde olması ve bazı ekonomik sıkıntılar sebep olmaktadır. Aliya konusunda gelinen son durum ise İsrail'den mülk satın almak şeklindedir. İsrail'e göçmeyi konumları itibariyle uygun görmeyen Avrupa ve ABD'deki bir kısım Yahudiler göçme ihtimallerine karşı buradan ev almaktadırlar (Bir Yükseliş Hikâyesi "Aliya". Şalom Gazetesi).

\section{Sonuç}

Aktarılan bilgiler doğrultusunda Kudüs için Yahudilerin en kutsal şehri demek yerine Tanrı'nın seçtiği yer demek daha uygun olacaktır. Kudüs'e göç, Yahudi geleneğinde de buna uygun şekilde yer almış ve MS 70'deki mabedin yıkılması ve büyük sürgünden sonra Kudüs'e toplu olarak Yahudilerin göçü uygun görülmemiştir. Eğer Tanrı isterse ibrahim'i Mezopotamya'dan nebi Musa'yı Mısır'dan ve 
Ezra'yla birlikte İsrailoğulları'nı Babil'den çıkardığı gibi yine dünyadaki Yahudileri Kudüs civarında toplayacağına inanılır. Yani bu Tanrı'nın isteğiyle ve istediği zaman gerçekleşecek bir olaydır. Bunun bir daha gerçekleşmesi konusundaki görüşlere ise kutsal metinler kaynaklık etmektedir. Dini metinlerden anlaşıldığı üzere Yahudilerden bu günün yani büyük göçün/toplu göç gelmesi için beklenenler dua etmek, tövbe etmek ve hallerini düzeltmeleridir. Diğer taraftan günümüzde Yahudilerin Kudüs'e göç konusundaki mevcut durumu ise bulundukları yerde antisemitik tehditler ile İsrail'de devamlı savaş tehdidi arasında bulunmaktadır. Antisemitik tepkilerden kaçarak geldikleri İsrail'de Filistin'in yerleşik halkına karşı tutumları nedeniyle de kurmaya çalıştıkları devlet huzuru yansıtmaktan oldukça uzaktır. 


\section{Kaynakça}

Arslantaş, N. (2011) İslami Dönemde (638-1099) Filistin'e Yahudi Göçü ('Aliya: עלייה). Belleten, LXXV, (274), 641-689.

Bir Yükseliş Hikâyesi "Aliya". Şalom Gazetesi. http://arsiv.salom.com.tr/news/print/6299-Bir-yukselishikayesi-Aliya.aspx adresinden 01 Nisan 2021 tarihinde erişildi.

Bleich, J. D. (1979). Judea And Samaria: Settlement And Return. Tradition: A Journal of Orthodox Jewish Thought, 20, (3), 4478.

Broshi, M. (1979). The Population of Western Palestine in the Roman-Byzantine Period. Bulletin of the American Schools of Oriental Research, 236, 1-10.

Cohon, S. S. (1925). Palestine in Jewish Theology. Hebrew Union College. 171-209.

Fayda, M. (1989). Hz. Ömer Zamanında Gayr-ı Müslimler. İstanbul: Marmara İlahiyat Fakültesi Yayınları.

Feyerabend, K. (ty.). A Complete Hebrew-English Pocket-Dictionary to the Old Testament. New York: The International News Company.

Gil, M. (1992). A History of Palestine 634-1099. Cambridge: Cambridge University Press.

Ginzberg, L. (1909). Geonica. Volume I. New York: The Jewish Theological Seminary of America.

Glass, J. B. (2018). From New Zion To Old Zion: American Jewish Immigration and Settlement in Palestine, 1917-1939. Michigan: Wayne State University Press. 
Güç, A. (2003). Çeşitli Dinlerde ve İslâm'da Kurban, İstanbul: Düşünce Yayınevi.

Hagopian, E. ve Zahlan, A. B. (1974). Palestine's Arab Population: The Demography of The Palestinians. Journal of Palestine Studies, 3, (4), 32-73.

Halamish, A. (2018). Immigration is Israel's History. So Far. Israel Studies, 23, (3), 106-113.

Hasanoğlu, E. (2015). Tanah'a Göre Kudüs'ün Kutsallaşma Süreci. Uludağ Üniversitesi Illahiyat Fakültesi Dergisi, 24, 125.148.

Hassan, S. (2017). Jewish Migration from Arab Lands 1947-1949. Indian History Congress, 78, 886-892.

Hayland, R. G. (1997). Seeing Islam as Other Saw it. Princeton: The Darwin Press.

İsrail Dış işleri Bakanlığı (1950). Law of Return 5710-1950. https://mfa.gov.il/mfa/mfa-archive/19501959/pages/law\%20of\%2oreturn\%205710-1950.aspx adresinden 3 Mart 2021 tarihinde erişildi.

Jewish Case: The Place of Palestine in the Solution of the Jewish Questions. (ty.). New York: American Palestine Committee and Christian Council on Palestine.

Louvish, M. ve Skolnik, F. (2007). "Aliyah". Encyclopaedia Judaica. F. Skolnik (Ed.). Thomson Gale: Macmillan.

Meral, Y. (2011) İbn Meymun'a Göre Yahudilik'te İman Esasları. Ankara Üniversitesi ilahiyat Fakültesi Dergisi, 52, (2), 243-266.

Midrash Rabbah. Genesis. (1961). (H. Freedman trans.), London: The Sancino Press. 
Oppenheimer, F. (1914). Merchavia: A Jewish Co-Operative Settlement in Palestine. New York: The Jewish National Fund Bureau For America.

Pittsburgh Platformu (1885). Declaration of Principles. Madde 5. www.ccarnet.org/rabbinic-voice/platforms/articledeclaration-principles/ adresinden 5 Mart 2021 tarihinde erişildi.

Ramban (Nachmanides). (1270). Hasagot HaRamban on Sefer HaMitzvot, Positive Commandments Omitted by Rambam, Mitzvah 4: 1. https://www.sefaria.org/Hasagot_HaRamban_on_Sefer_Ha Mitzvot\%2C_Positive_Commandments_Omitted_by_Ramba m.4.1 1 lang=en\&with=Deuteronomy\&lang2=en adresinden 3 Mart 2021 tarihinde erişildi.

Raphael, M. L. (1973). Rabbi Jacop Voorsanger of San Francisco on Jews and Judaism: The Implications of the Pittsburgh Platform. American Jewish Historical Quarterly, 63(2), 185203.

Schechter, S. (2007). A Dream of Zion: American Jews Reflect on Why Israel Matters to Them. J. K. Salkin (Ed.) Woodstock: Jewish Lights Publishing.

Scholch, A. (1992). Britain in Palestine, 1838-1882: The Roots of the Balfour Policy. Journal of Palestine Studies, 22(1), 39-56.

Schwartz, J. (1981). Babylonian Commoners in Amoraic Palestine. Journal of the American Oriental Society, 101(3), 317-322.

Sidur K. Y. (2006). Liliane Zerbib Kazes. İstanbul: Gözlem Yayınları. 
Siegel, S. N. (2018). A new Exodus? Explaining Jewish Migration from Europe after the Cold War. Journal of Modern Jewish Studies, 17(4), 416-433.

The Apocalypse of Abraham. (1919). (G. H. Box, Trans.). New York: Macmillan Company.

The Babylonian Talmud. (1935). (I. Epstein, Ed.), London: The Soncino Press.

The Jewish Virtual Library. Aliyah in Judaism. https://www.jewishvirtuallibrary.org/aliyah adresinden 2 Şubat 2021 tarihinde erişildi.

The Jewish Virtual Library. Israel Studies An Anthology. https://www.jewishvirtuallibrary.org/israel-studies-ananthology-immigration-in-israel adresinden 31 Mayıs 2021 tarihinde erișildi.

The Mishnah. (1933). (H. Danby, trans.). New York: Oxford University Press.

Zakutinsky A. (2016). Is Aliyah a Mitzvah? https://www.ou.org/blog/isaliyah-a-mitzvah/adresinden 3 Mart 2021 tarihinde erişildi. 